\begin{tabular}{c} 
GEOSPORT FOR SOCIETY \\
$\begin{array}{l}\text { SEOSPORT } \\
\text { SOCIETY }\end{array}$ \\
Scientific Journal founded in 2014 under aegis of University of Oradea (Romania), \\
University of Debrecen (Hungary), University of Gdánsk (Poland) \\
ISSN 2393-1353 \\
Edited by Oradea University Press \\
1, University Street, 410087, Oradea, Romania \\
Journal homepage: $h$ ttp://geosport.uoradea.ro/geosport.html \\
\hline \hline
\end{tabular}

\title{
Sport and adventure in the Pădurea Craiului Mountains
}

\author{
Varodi Mihaela OLĂU ${ }^{1 *}$, Dana Ioana CRISTEA², Anca-Cristina POP ${ }^{3}$, Maria GOZNER ${ }^{4}$
}

1. Ph.D. candidate, University of Oradea, Department of Geography, Tourism and Territorial Planning, 1 University St., 410087 Oradea, Romania, e-mail: oradeanu_miha@yahoo.com

2. University of Oradea, Department of Physical Education, Sport and Physical Therapy, 1 University St., 410087 Oradea, Romania, e-mail: danacristea07@yahoo.com

3. University of Oradea, Department of Physical Education, Sport and Physical Therapy, 1 University St., 410087 Oradea, Romania, e-mail: popancacristina@yahoo.com

4. University of Oradea, Department of Geography, Tourism and Territorial Planning, 1 University St., 410087 Oradea, Romania, e-mail: mariagozner@yahoo.com

* Corresponding author

Citation: Olău, V. M., Cristea, D. I., Pop, A.-C., \& Gozner, M. (2019). Sport and adventure in the Pădurea Craiului Mountains. Geosport for Society, 11(2), 48-58. https://doi.org/10.30892/gss.1101-048

Article history: Received: 03.05.2019; Revised: 12.07.2019; Accepted: 20.08.2019, Available online: 05.09.2019

\begin{abstract}
The term of tourist product, as it was understood in the first decade after December, has undergone an important change of meaning, in the age of today's tourist. The simple outings in nature are replaced by trekking and cycle tourism tours, the classical mountain climbing by sport climbing, via ferrata, rafting and canyoning, wandering through caves by speotourism and the list may continue. Finally, we realize that the era of speed and the Internet brings along a paradigm change in terms of the tourist offer: adaptation to the need for adrenaline is done through extreme sports and adventure tourism services. The present study aims to highlight some recreational and leisure, sportive and adventure activities: caving tourism, mountain climbing, sport climbing, via ferrate, mountain hiking, cycle tourism, zip line and rafting, all happening in Pădurea Craiului Mountains. If the above assertion seems generally valid, this area is perfectly in line with the trends, the tourism operators offer the most diverse activities, to meet the growing demand of new tourist products.
\end{abstract}

Keywords: biking, adventure, caving, climbing, trekking, rafting, via-ferrata

\section{Introduction}

The contemporary sports phenomenon achieves multidisciplinary valences from the social, economic, geographical and cultural point of view (Buhaș, 2015; Buhas et al., 2017; Kozma, 2014; Gaceu et al., 2015; Dragoș et al., 2017; Tătar et al., 
2018; Chirazi, 2019). The specialty studies have indicated a close link between sportswe include here tourism as a sport activity and their geographical distribution (Herman et al., 2016a, b). Moreover, for optimal information and representation, maps have been designed using the GIS tools cartographic method (Andronache et al., 2019; Baias et al., 2010; Herman, 2010; Ilies et al., 2011, 2016, 2017; Herman et al., 2016c; Herman and Grama, 2018; Romocea et al., 2018).

The quality and quantity of the sports offer evolve in parallel with the growth of the number of the participants, because, to practice sports has become for many people a way of personal highlighting and even a way of life as Binkowska-Bury, Penar-Zadarko say, 2009, quated by Lucaciu, 2012.

Tourism is one of the means of physical education, along with gymnastics, playing and dancing (Cîrstea, 1993; Dragnea \& Bota, 1999). A definition among the many accepted, describes tourism as „a set of measures applied for organizing and carrying out some leisure trips or for other purposes, made either through organizations, societies or specialized agents, or on their own, for a limited time, as well as the industry that compete to fulfill the tourists' needs" (Minciu, 2002,14-15).

The form of tourism highlights the concrete way and the circumstances in which tourism is practiced. The type is connected to the essence of tourism, and the form to the nature of its manifestation. Summarizing the previous classifications I. Mac (quoted by Măhăra, 1995), distinguishes four types of tourist activities:

A. Free time tourism:

a -recreational tourism (walking, hiking, trips, holidays);

$\mathrm{b}$-recreational and health care tourism;

c -visiting tourism (cultural, social, family, religious);

d -short distance tourism;

B. Transit tourism (volunteer and conditional);

C. Cultural and sport tourism (folkloric manifestations, festivals, sport competitions etc.)

D. Professional tourism (scientific, cultural, technical, business, diplomacy).

Another classification (Cocean, 1997) delineates the following types of tourism: recreational tourism; health care tourism; cultural tourism; complex tourism (recreational and business, recreational and information, etc).

Tourism is, by its impact and consequences, an industry becoming more and more important, a vital component of economic and social life for a growing number of countries, for some being the only real chance of economic success (Minciu, 2002; Fieroiu, 2008; Morar \& Pop, 2016). Through its own and propagated characteristics also, tourism stands out in almost all countries as an activity with a high degree of economic efficiency in comparison with other sectors of the national economy (Bran et al., 2000). The ones 
who want to practice tourism are not conditioned by certain qualities, skills or physical aptitudes, and boundaries of age does not exist (Lucaciu, 2013).

Mountain tourism is a phenomenon that implies many different aspects, involving a large number of activities -some of them seasonal -into and out of" fashion". After coastal areas and islands, mountains are the most important destination in the world tourism, accounting for about $15-20 \%$ of it (over 50 million people annually visit the mountains), which is an annual contribution of about 70-90 billion dollars to the world economy after 1990 with an annual growth rate of 4.7\%; for the next two decades is expected a growth rate of $4.1 \%$, being one of the most dynamic global industry (Lucaciu, 2013, 2015).

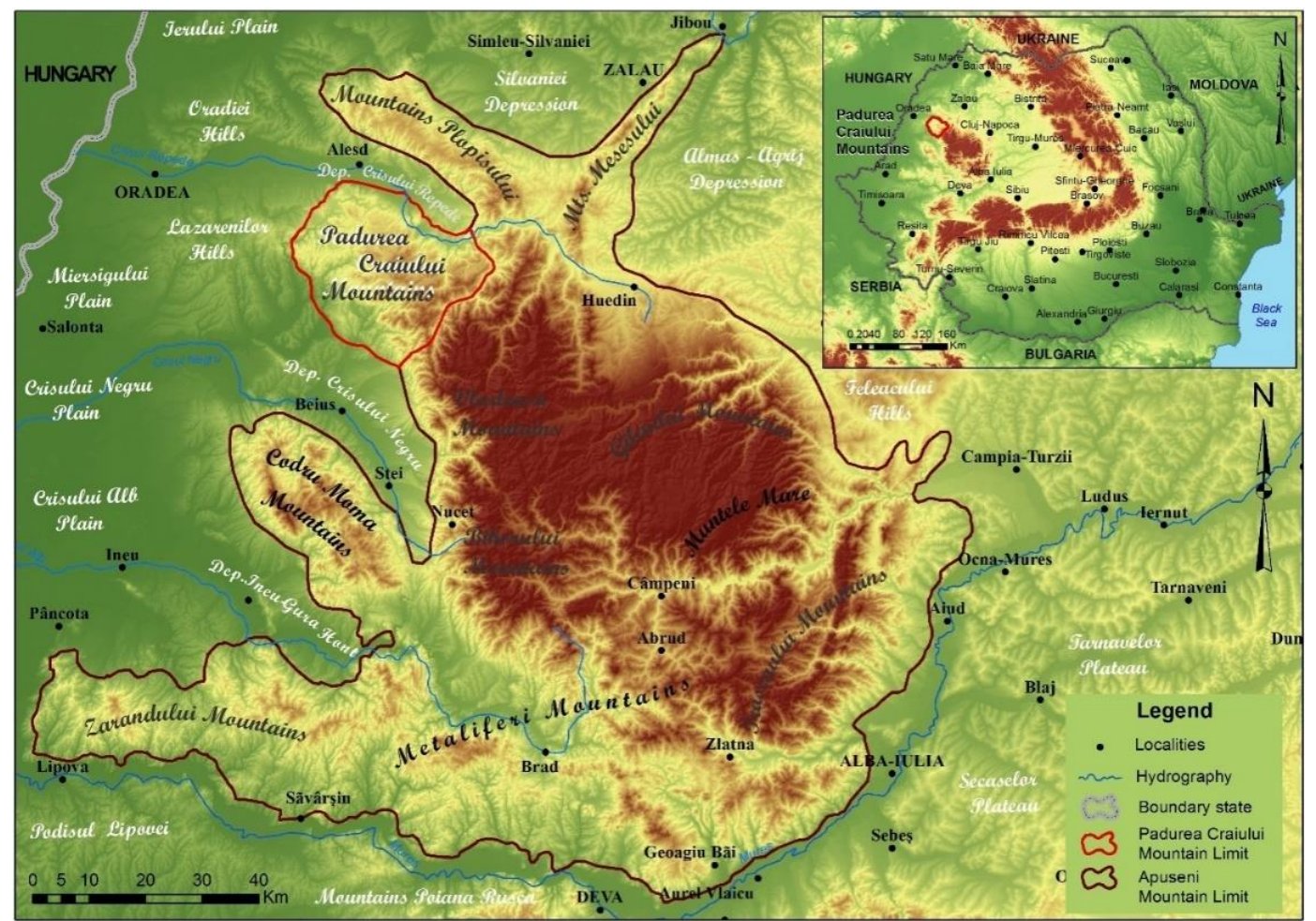

Figure 1. Geographic location of the Pădurea Craiului Mountains in the Apuseni Mountain and in Romania

The significant natural and anthropic tourism potential of the Pădurea Craiului Mountains (figure 1) puts this mountain group into the category of those favorable to the appearance and development of all types of tourism. Low altitudes, accessibility, the presence of Karst relief, the traditional village with all its elements create the conditions for recreational tourism, cultural, rural, ecotourism and also for the health care one, of course with differences regarding the number of the tourists 
involved (Herman et al., 2019). Recreational and leisure tourism is detached by age and by the significant number of tourists, its forms such as mountain hiking, caving tourism and mountain climbing have an old and continuous tradition, with origins that date back to the nineteenth century.

The most representative physical activities that are practiced in the Pădurea Craiului Mountains are caving tourism, mountain and sport climbing, mountain hiking with old tradition or more recent forms, very well received among tourists such as rafting, via ferrata, cycle tourism, zip line, sport fishing, rafting and canoeing.

The popularity of the area for caving tourism is favored by the presence of an impressive number of caves and pit caves (vertical caves), 1308 according to Cocean (2000), from which 4 caves arranged for mass tourism. Mountain/sport climbing is currently practiced in six areas spread throughout the region.

Crisul Repede Gorges is a climbing area which is well known nationally. Hiking imposed by wide accessibility and freedom, both on long marked trails and also on shorter distances in the whole mountain group. The other forms of adventure tourism such as rafting, via ferrate or zip line have an increasing number of practitioners, enlarging the tourist offer in less attractive areas, revitalizing old routes or creating real adventure areas such as the area of Unguru Mare Cave.

\section{Research Methodology}

The methodology used in this material contributes to a better knowledge of Pădurea Craiului Mountains as tourist destination. The information and data analyzed in this study are from the domains of geography and sports. In what methodology is concerned, a series of classical research methods were used (observation and description), as well as a series of modern means. The relevant data were gathered from a variety of sources. The method of bibliographic documentation (Cocean, 2005) was followed by field investigations with the help of proper techniques. The bibliographic documentation included the consultation of specialty literature and documentary sources. The cartographic material was elaborated by using specialized software such as ArcGIS and Microsoft Excel. The method of synthesis led to conclusions referring to relations between nature and tourism, representing an objective and practical perspective of the key tendencies in tourism development.

\section{Caving tourism}

Mass caving tourism has very good development premises in the Pădurea Craiului Mountains, at the moment there are four caves exploited in this way Vadu Crișului Cave and Unguru Mare Cave in the north west of the mountain group and Meziad Cave and Farcu Mine in the south-west, their position in the mountains allows a balanced development of the tourism in that area. These four caves are well-known 
tourist attractions at regional and national level, with great opportunities for opening up to international tourism, attracting a big number of visitors (figure 2).

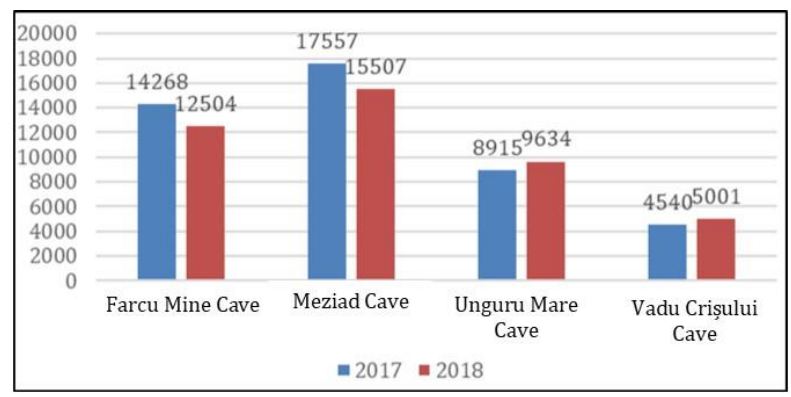

Figure 2. The number of visitors on each location in the years 2017-2018

(Source: CAPDD, Bihor, 2019)

According to some authors, (Cocean, 1995) many caves from the Pădurea Craiului Mountains spread in the whole region present a great variety in terms of attractive resources (magnitude and length of the cavern, variety of morphology, watercourses, the presence of underground lakes or waterfalls, richness and variety of speleothems, the underground climate, paleontological and archaeological vestiges), accessible position, or arrangement possibilities, attributes that position this mountain group on the map of national and European caving tourism.

Cocean (1995) identifies from the approximately 11.000 caves from Romania, 144 caves with tourist potential from which 19 are in the Pădurea Craiului Mountains, this mountain group being exceeded only by Bihorului Mountains.

Specialized caving tourism is practiced as a result if implementing the project , The first network of tourist caving from Romania” sustainable valorization of karstic patrimony of those from CAPDD Bihor in 2016. The project objective - protection, integrated and active conservation through tourist capitalization of 10 tourist caves from the Pădurea Craiului Mountains, is reached through clear regulations regarding the access but also through promoting actions that have put the Pădurea Craiului Mountains on the map of the national and international speleological tourism. These 10 caves are classified into three degrees of difficulty: Discover for beginners, Experience - medium difficulty and Explore- for advanced. 1

\section{Mountain and sport climbing}

In the classic sense mountain climbing represents the ascent to the alpine peaks from the mountain area of high altitude, often covered with snow and ice. The aim of the ascent is to reach the summit with the help of the equipment provided-rope, ice

\footnotetext{
1 https://www.padureacraiului.ro/speoturism
} 
ax, crampons, pitons and safe descent at the base of mountain. Currently, climbing is done in two -man teams- lead climber and following climber. Climbing implies the ascent of the lead climber while the following (safety) climber assures him by regrouping (an easier section where anchors are mounted) allowing then the safety climber to start the climbing once the lead climber has mounted a new regrouping and ensures in turn the safety climber. Regrouping climbing repeats itself until the top of the mountain is reached; their number defines the length of the route expressed in „rope lengths”.

Mountain ascents follow either predetermined classic routes or new routes (FA-first ascents) and imply installing the anchors by the climbers. The anchors are fixed (pitons) or mobile (nuts and friend's devices) and their aim is to fix the rope for assisting the lead climber.

Sport climbing, on the other hand, implies climbing on vertical rock walls with the help of your own forces, which means just by using hands and legs in the ascent, technical accessories are used only to belay the climber.

The aim of climbing vertical walls is rather a personal one; the competition is about winning the fight with gravity and your own physical and mental limits, by positioning the body in balance on the rock and by correct dosage of the effort to complete the route.

The equipment involves climbing rope, quick draws (couple of snap gate carabiners and a sling), the safety device (for blocking the rope in case of a fall), harness, climbing shoes and chalk bag. Anchors in sports climbing are fixed and permanent, mounted according to the expansion bolts technique and has a metallic hanger for fixing the rope by the mean of quick draws.

In sports climbing the routes have most often a single rope length (top rope), rarely two or three. Of course, this fact is mainly due to the low altitude of some climbing areas such as cliffs, stone quarries, gorges and passes from the Pădurea Craiului Mountains. Teams can either follow the classic pattern on the routes with more rope lengths, or gather more teammates, usually a monitor who belays the other climbers.

An alternative for climbing is bouldering which is a form of climbing that is performed on very short and difficult routes (2-3 meters) and which only requires a mattress at the base of the route as a safety technique. For mountaineering and climbing practitioners from nearby counties, Pădurea Craiului Mountains is a muchfrequented destination. The large number of routes, accessible areas, different degrees of difficulty (Anghel, 2007) represents the strengths for these mountains to be chosen as a destination by the people who love this sport. In Pădurea Craiului Mountains there are currently six climbing areas: Vadu Crișului, Șuncuiuș, Bulz, Remeți, Osoi and Lazuri, with a total of 442 routes. The oldest climbing area, thus with 
the most routes is Vadu Crișului, with 20 sectors, a result of 281 routes with different rope lengths and different degrees of difficulty, from which two recent routes of via ferrata: The Fairy Wall (Peretele Zânelor) and Ogre's House (Casa Zmeului), ${ }^{2}$ which makes use of two old mountaineering routes. From the analysis of the information provided by Bihor Mountain Rescue we may conclude the following: many of the old mountaineering routes have been re-equipped in the last years according to sports climbing (free climbing) standards, which shows a reorientation towards the old and picturesque climbing routes of the young climbers, exploiting thus the sectors left behind and integrating into the tourist circuit new climbing areas. Osoi area, on the wall that houses the eponymous cave, from Vârciorog with 30 routes, many of them of medium level, more accessible, including for kids, and Lazuri Gorges, in Lazuri, Roșia, 48 routes, also of medium level of difficulty, which shows openness to this sport from both ways, both from the hikers who promote it so that it does not remain a niche sport and from mountain lovers for which it becomes more accessible. Both areas have been recently inaugurated, Osoi in the autumn of 2017, Lazuri in the spring of 2018, during climbing festivals with hundreds of participants, both from the country and abroad.

\section{Via ferrata}

Via ferrata (iron trails) in Italian - translated as iron road - are routes equipped with iron steps, metal struts, fixed ladders, cables and bridges and becoming more and more popular in our country. These allow tourists who are less familiar with mountaineering/sports climbing to climb vertical trails of different lengths on rocky walls in safe conditions. The beginnings of via ferrata are linked to the World War I and the attempts of the soldiers from the Dolomites Alps to make their ascent easier.

The via ferrata routes are classified according to their level of difficulty from $\mathrm{A}$ (easy) to E (extremely difficult). The necessary equipment is climbing harness, via ferrata set (detachable set of ropes with carabiners which you will connect to the steel wire on the via ferrata trail), helmet and maybe gloves.

In Pădurea Craiului Mountains there are three via ferrata trails integrating from this point of view the mountain group in the top existing at national level: Mocănița (Steam Train)- 2015, difficulty B and Ogre's House-2017, difficulty C in Passes of Crisul Repede, near Vadu Crișului made by the County Mount Rescue Service; Salvaspeo Bihor and Cassio Montana Bihor Club. Both of them value old climbing trails of several rope lengths. The trail from the adventure park Montana Land, from Șuncuiuș made by the Cassio Montana Bihor Club in April 2018. The access in the route of B difficulty, with a length of $170 \mathrm{~m}$ has a tax unlike those from Vadu Crișului 
where access is free. ${ }^{3}$ Also, in Șuncuiuș, Hodoaba Valley route situated on the wall of Unguru Mare Cave, degree of difficulty A, with a length of $42 \mathrm{~m}$, equipped by County Mount Rescue Service- Salvaspeo Bihor.

\section{Cycling tourism}

Cycling routes uses the existing communication infrastructure, county roads, communal and forest roads or hiking trail sectors. CAPDD Bihor outlined and then marked routes within the projects carried out nine themed cycle tours, of different lengths and degree of difficulty towards different tourist attractions, traditional households, spectacular and picturesque landscapes from the Pădurea Craiului Mountains. Therefore, there are available for tourists 12 bicycles equipped for mountain bike and trails with maps or GPS at the renting centers Remetea that function within the campsite Turul and Roșia at the Nature 2000 Site Visiting Centre or may be transported at request anywhere within the area of the Pădurea Craiului Mountains. Most of the trails are difficult (six of the nine proposed), two of medium level and one trail is easy, which make them not so accessible to mass tourism though the Pădurea Craiului Mountains have a huge potential in this regard.

\section{Zip line}

Zip line, aerial crossing over a steep valley with the help of a fixed cable between two points and a pulley, can be tried in Roșia commune beneath the Mina Farcu cave, where it has a length of $300 \mathrm{~m}$, being the second long one in the country, at Meziad cave with a length of $100 \mathrm{~m}$.

\section{Rafting}

Practicing water sports on mountain rivers, such as rafting, is very popular in mountain areas. Bihor County was the first area to have promoted this kind of activity in Romania, through the potential assessment project, on mountain rivers from Romania, developed in 2004 by Bihor Association of Mountain Rescuers. 4

Regarding the study area, rafting is getting more and more popular, is being practiced in the Crisul Repede Gorges, from Bratca up to Vadu Crișului. The part between Bălnaca and Șuncuiuș is very often used for rafting because during summer there is the possibility to rent boats at the entrance area on Mișidului Valley (Pop, 2014).

From the practiced physical activities, rafting has an ascending trend, being the most requested sport for operators in the area. In 2018 it had the percentage of $44,91 \%$ tourists from the total of those who requested activities offered by operators (figure 3 ).

\footnotetext{
3 https://viaferrataromania.wordpress.com/
}

${ }^{4}$ http://www.cjbihor.ro/pdf/Strategia\%20pentru\%20dezvoltarea\%20durabila\%20a\%20judetului\%20Bihor\%202014-2020.pdf 


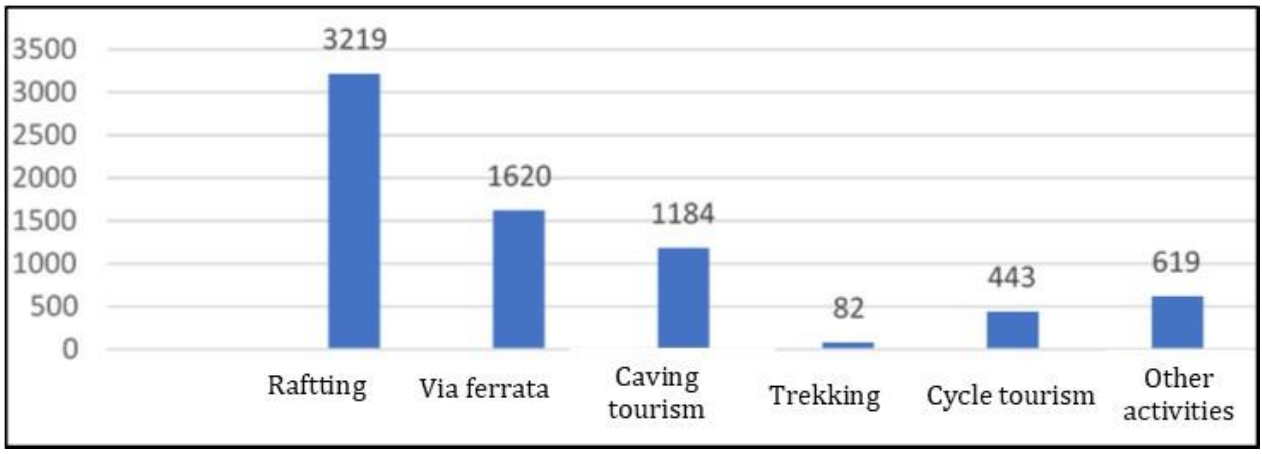

Figure 3. Number of tourists on activities in 2018 (source: CAPDD Bihor, 2019)

\section{Mountain running}

The rough terrain and altitudinal differences make the Pădurea Craiului Mountains a place for mountain running even if from the altitude point of view, they do no register for this form of sports tourism. As a result, in 2019 five running trails were marked in this area, three in Șuncuiuș area and two in Roșia area, from which two easy, two medium/difficult and one difficult 5

Starting with the year 2017, an important mountain running competition has been held in Șuncuiuș-Primavera Trail Race that gathers the fans of this sport which is practiced by more and more mountain lovers and which was the basis for the subsequent marking of the routes. The entire space of the Pădurea Craiului Mountains offers ideal places for carrying out such competitions/ regular meetings.

\section{Conclusions and proposals}

The studied area offers the possibility to practice many physical activities but we have to meet the expectations with certain facilities that regards the accommodation offer, food, transport, entertainment and not lastly easy access and arranged parking lots. The entertaining side and the opportunities to spend free time are poorly developed in this area. Still, one thing has to be mentioned, the proximity to big Romanian cities, such as: Oradea, Cluj Napoca, Arad, and the western border could attract a considerable number of foreign tourists, resolving this issue to a certain extent. By organizing competitions at national and international level, tourism could develop in this area, by involving various actors: competitors, organizers, spectators and supporters. 


\section{References}

Andronache, I., Marin, M., Fischer, R., Ahammer, H., Radulovic, M., Ciobotaru, A. M., Jelinek, H. F., Di Ieva, A., Pintilii, R.-D., Drăghici, C.-C., Herman, G. V., Nicula, A.-S., Simion, A.-G., Loghin, I.-V., Diaconu D.-C. \& Peptenatu D. (2019). Dynamics of Forest Fragmentation and Connectivity Using Particle and Fractal Analysis. Scientific Reports, 9(1), 1-9.

Anghel, D. (2007). Munții Apuseni. Ghidul traseelor de escaladă [Apuseni Mountains; Climbing routes guide], Editura GrafNet, Oradea.

Baias, S., Blaga, L., Dehoorne, O., Grama, V., Gozner, M., Herman, G. V., ... \& Morar, C. (2010). Băile FelixBăile 1 Mai-Betfia (județul Bihor), Harta geoturistică. Editura Universității din Oradea, Oradea.

Bran, F., Simion, T., \& Nistoreanu, P. (2000). Ecotourism [Ecotourism], Editura Economică, București.

Buhaș, D. S., Herman, G. V., Paul, F. D., \& Stance, L. (2017). Football and economy before and after communism in Romania. GeoSport for Society, 6(1), 30-39.

Buhaș, S. D. (2015). Sport management. From institutionalism to research. Geosport for Society, 2(1), 26-32.

Cârstea, G. (1993). Teoria şi metodica educaţiei fizice şi sportului [Theory and methodology of physical education and sport], Editura Universul, Bucureşti.

Chirazi, M. (2019). Comparative evolution of the phenomenon of geography of sports on national and global levels. Geosport for Society, 10(1), 7-14.

Cocean, P. (1995). Peșterile României. Potențial turistic [The caves of Romania. Tourist potential], Editura Dacia, Cluj-Napoca.

Cocean, P. (1997). Geografia turismului românesc [The geography of Romanian tourism], Editura Focul Viu, Cluj- Napoca.

Cocean, P. (2000). Munții Apuseni. Procese și forme carstice [Apuseni mountains. Karst processes and forms], Editura Academiei Române.

Dragnea, A., \& Bota, A. (1999). Teoria activităților motrice [Theory of motor activities], Editura Didactică și Pedagogică, București.

Dragoș, P., Szabo-Alexi, M., Szabo- Alexi, P., Ilieș, D. C., Gozner, M., Marcu, F., Iovan, C., Buhaș, S., Pop, A.C., Dumbravă, R., \& Stance, L. (2017). Investigation concerning the influence of sports trainings carried out in a protectid area (Natura 2000 site) on various physiological and biological parameters for athletes. GeoSport for Society, 6(1), 40-46.

Fieroiu, B. (2008). Turismul montan mijloc de educare și formare a personalitații umane [Mountain tourism means of education and training of the human personality], Teză de doctorat, Universitatea din Pitești.

Gaceu O., Zarrilli, L., Gozner, M., \& Pop, A. C. (2015). Snow cover in support of developement of winter tourism activities in Muntele Băișorii resort. Geosport for Society, 2 (1), 7-20.

Herman G. V. (2010). Using Geographical Information (GIS) System for Management of Flood Risks in the Somes Plain, in Cross-Border Partnership with Special Regard to the Hungarian - Romanian Ukrainian Tripartite Border, Book Editors Ioan Horga, Istvan Suli Zakar, Publishing House University of Debrecen Press, p. 175 -179.

Herman, G. V., \& Grama, V. (2018). Geographical Aspects of Space-Time Evolution of Independent States. Revista Română de Geografie Politică, 20(2): 49-56.

Herman, G. V., Buhaș, S. D., Stance, L., \& Pop, A. (2016a). Considerations regarding the evolution, distribution and dynamics of the romanian football (League I) between 1989 - 2016. GeoSport for Society, 5(2), 69-78.

Herman, G. V., Grama, V., \& Stupariu, I. M. (2016b). The international organisation between globalization and regionalization. Case study: World Tourism Organization. Revista Română de Geografie Politică, 18(2): 49-59.

Herman, G. V., Ilieș, D. C., Baias, Ș., Măduța, M. F., Ilieș, A., Wendt, J., \& Josan, I. (2016c). The tourist map, scientific tool that supports the exploration of protected areas, Bihor County, Romania. GeoSport for Society, 4(1), 24-32.

Herman, G.V., Varodi, M.O., Grama, V., \& Morar, C. (2019). Geographical Considerations Regarding the Tourist Destination Pădurea Craiului Mountains. Analele Universităţii din Oradea, Seria Geografie, 29(1), 102-108.

Ilieș, A., Wendt, J. A., Ilieș, D. C., Herman, G. V., Ilieș, M., \& Deac, A. L. (2016). The patrimony of wooden churches, built between 1531 and 2015, in the Land of Maramureș, Romania. Journal of Maps, 12(sup1), 597-602. 
Ilieș, D. C., Herman, G., Ilieș, A., Baias, Ș., Dehoorne, O., Buhaș, S., \& Ungureanu, M. (2017). Tourism and Biodiversity in Natura 2000 Sites. Case Study: Natura 2000 Valea Roșie (Red Valley) Site, Bihor County, Romania. Études caribéennes, (37-38).

Ilieș, D. C., Ilieș, A., Herman, G. V., Baias, Ş., \& Morar, C. (2011). Geotourist map of the Băile Felix-Băile 1 Mai-Betfia area (Bihor County, Romania). GeoJournal of Tourism and Geosites, 2(8), 219-226.

Kozma, G. (2014). The spatial development of sports facilities within the cities: A Central European case study. Geosport for Society, 1(1-2), 19-28.

Lucaciu, G. (2015). Analiză calitativă a turismului montan în zona Padiş din Munţii Apuseni -România [Qualitative analysis of mountain tourism in Padiş area from Apuseni Mountains -Romania]. Analele Universităţii din Oradea. Fascicula Educaţie Fizică şi Sport, 25, 39-45.

Lucaciu, G., \& Lucaciu, S., (2012). Perspective ale turismului montan ca mijloc de loisir [Perspectives of mountain tourism as a means of leisure]. Analele Universităţii din Oradea. Fascicula Educaţie Fizică şi Sport, 22, 28-33.

Lucaciu, G., Preda, V., \& Lucaciu, S. (2013). Progress of social groups relations in mountain tourism. Analele Universităţii din Oradea. Fascicula Educaţie Fizică şi Sport, 23, 28-32.

Măhăra, G. (1995). Geografia turismului [Tourism Geography], Editura Universităţii din Oradea, Oradea.

Minciu, R. (2002). Economia turismului (ediţia a II-a revăzută) [Tourism economy (revised 2nd edition)], Editura Uranus, București.

Morar, C., \& Pop, A. C. (2016). Water, tourism and sport. A conceptual approach. GeoJournal of Tourism and Geosites, 18(2), 249-258.

Pop, A. C. (2014). Modele de amenajare turistică pentru practicarea activităților recreative și sportive în cadrul Muntilor Apuseni [Models of tourism planning for recreational and sports activities in the Apuseni Mountains], Editura Universității din Oradea, Oradea.

Romocea, T., Oneț, A., Sabău, N.C., Oneț, C., Herman, G.V., \& Pantea, E. (2018). Change of the groundwater quality from industrial area Oradea, Romania, using Geographic Information Systems (GIS). Environmental Engineering \& Management Journal (EEMJ), 17(9): 2189-2199.

Tătar, C. F., Herman, G. V., \& Pețan, P. (2018). Sport and physical activity engagement in Romania. Geosport for Society, 8(1), 40-50.

\section{Web-sites sources:}

http://alpinismbihor.ro(accessed at: 21.09.2018);

http://www.cjbihor.ro/pdf/Strategia\%20pentru\%20dezvoltarea\%20durabila\%20a\%20judetului\%20 Bihor\%202014-2020.pdf (accessed at:02.01.2019);

https://padureacraiului.ro/alergare-montana/ (accessed at: 18.10.2018);

https://www.padureacraiului.ro/speoturism (accessed at:18.10.2018);

https://viaferrataromania.wordpress.com/ (accessed at: 20.02.2019). 